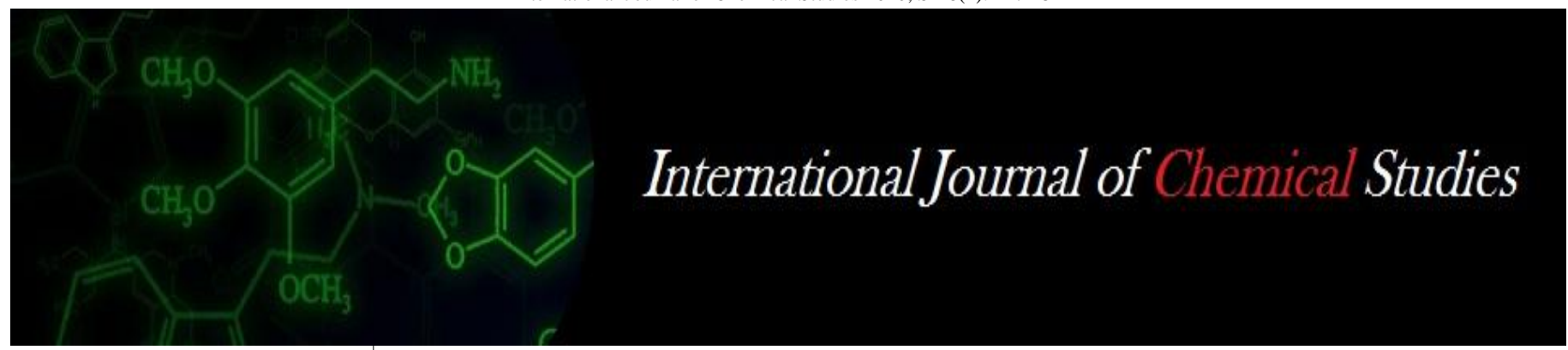

P-ISSN: 2349-8528

E-ISSN: 2321-4902

www.chemijournal.com

IJCS 2020; SP-8(2): 147-154

(C) 2020 IJCS

Received: 22-01-2020

Accepted: 25-02-2020

Saurabh

Ph.D. Scholar, Department of

Veterinary Gynecology \& Obstetrics,

College of Veterinary Science \& Animal

Husbandry, Acharya Narendra Deva

University of Agriculture \& Technology,

Ayodhya, Uttar Pradesh, India

Sushant Srivastava

Professor, Department of Veterinary

Gynecology \& Obstetrics, College of

Veterinary Science \& Animal

Husbandry, Acharya Narendra Deva

University of Agriculture \& Technology,

Ayodhya, Uttar Pradesh, India

Anand Kumar

M.V.Sc. Scholar, Department of

Veterinary Gynecology \& Obstetrics,

College of Veterinary Science \& Animal

Husbandry, Acharya Narendra Deva

University of Agriculture \& Technology,

Ayodhya, Uttar Pradesh. India

Pushkar Sharma

Ph.D. Scholar, Department of

Veterinary Gynecology \& Obstetrics,

College of Veterinary Science \& Animal

Husbandry, Acharya Narendra Deva

University of Agriculture \& Technology,

Ayodhya, Uttar Pradesh, India

RK Doharey

Professor Assoc Dean, Department of Agri. Extension, College of Agriculture, Acharya Narendra Deva University of Agriculture \& Technology, Ayodhya,

Uttar Pradesh, India

\section{VK Singh}

Professor, Animal Genetics \& Breeding, College of Veterinary Science \& Animal Husbandry, Acharya Narendra Deva University of Agriculture \& Technology, Ayodhya, Uttar Pradesh, India

\section{Vinay Kumar}

SRF, IIPR, Kalyanpur, Kanpur, Uttar Pradesh India

\section{Current perceptive on canine cystic endometrial hyperplasia-pyometra syndrome-A review}

\author{
Saurabh, Sushant Srivastava, Anand Kumar, Pushkar Sharma, RK \\ Doharey, VK Singh and Vinay Kumar
}

DOI: https://doi.org/10.22271/chemi.2020.v8.i2c.9772

\begin{abstract}
Cystic endometrial hyperplasia-pyometra complex $(\mathrm{CEH} / \mathrm{P})$ is a life-threatening challenge in canine reproduction. Hormonal imbalances result in environmental and histological changes in the uterus leading to a predisposition to bacterial growth. Haematological analysis shows the total number of leucocytes is frequently elevated in cases of pyometra, although the degree is much less marked in cases of open cervix pyometra compared with closed cervix pyometra. Ovariohysterectomy is the treatment of choice for closed cervix or open cervix pyometra. If the condition is not life-threatening and the animal is enrolled in breeding programmed or particularly valuable or when the clinical situation precludes surgery, medical treatment may be considered.
\end{abstract}

Keywords: Uterus, cystic endometrial hyperplasia (CEH), hormones, canine pyometra, aglepristone

\section{Introduction}

During estrus cycle, the uterus of female dogs undergoes different morphological changes under the influence of progesterone and estrogen. Cystic endometrial hyperplasia is an abnormal response of non-castrated canine uterus under these ovarian hormones. Cystic endometrial hyperplasia and pyometra complex $(\mathrm{CEH} / \mathrm{P})$ represents a common life-threatening challenge in small animal reproduction (Pretzer, 2008; Melandri et al., 2019) ${ }^{[37,30]}$. Cystic endometrial hyperplasia (CEH)-pyometra syndrome is an acute or chronic, poly-systemic, diestrual disorder of non-castrated bitch characterized by hyperplasia of the endometrium and infiltration of inflammatory cells, which may be present in all layers of the uterus (Dow, 1957; Kennedy et al., 1993 $)^{[9,29]}$. However, during the animal's life, there is progressive hyperplasia, which ultimately results in the development of pathological lesions termed cystic endometrial hyperplasia several authors suggested that pyometra should be classified as CEH-pyometra complex because sub-acute endometritis later develops as $\mathrm{CEH}$ is the most important predisposing factor of pyometra (Sandholm et al., 1975) ${ }^{[39]}$. Others suggest that CEH and pyometra should be classified separately based on differences in clinical and histopathological findings (Debosscher, et al., 2001) ${ }^{[8]}$. It is common to see pyometra defined as the endometritis/cystic endometrial hyperplasia/pyometra complex (CEH/P) (Arora et al., 2006) [3].

Pyometra can be defined as the pathological condition of uterus in which, there is an accumulation of purulent semisolid-liquid material inside the uterine lumen of intact bitches, generally during post progesterone dominant phase of the estrous cycle. Canine Pyometra can be classified based on the status of the cervix may be two types open-cervix and closed-cervix. Closed-cervix pyometra is a particularly more dangerous condition in comparison to open cervix because septicemia and toxemia may develop rapidly and left untreated can result in patient death. However closed-cervix pyometra needs surgical intervention to prevent its progression to sepsis and fatality in non-castrated bitch (Smith, 2006) ${ }^{[45]}$.

\section{Prevalence and History}

Pyometra has consistently been shown to predominantly affect middle-aged to older-aged non castrated bitches, with mean age varying from 6.4 to 9.5 years (Dow, 1958; Ewald, 1961; Hardy 1974; Wheaton et al., 1989; Sevelius et al., 1990; Niskanen and Thrusfield, 1998; Egenvall et al., 2001; Fukuda, 2001; Whitehead, 2008; Igna, 2011; Hagman et al., 2011) [10, 14,
Corresponding Author
Sushant Srivastava

Professor, Department of Veterinary Gynecology \& Obstetrics, College of Veterinary Science \& Animal Husbandry, Acharya Narendra Deva University of Agriculture \& Technology, Ayodhya, Uttar Pradesh, India 
23, 46, 40, 34, 11, 16, 47, 26, 22]. Most researchers are given the opinion that $\mathrm{CEH}$ is a spontaneously occurring disease of middle-aged or old bitches (Moxon et al., 2016) ${ }^{[32]}$. Jitpean et al., $2014^{[27]}$ reported disease occurrence was $19 \%$ in bitches below 10 years of age and $20 \%$ in older female dogs.

High breed susceptibility is also observed in this condition include Rottweiler, Saint Bernard, Chow chow, Golden Retriever, Miniature Schnauzer, Irish Terrier, Airedale Terrier, Cavalier King Charles Spaniel, Rough Collie, and Bernese Mountain dog (Smith, 2006) ${ }^{[45]}$. However, a few breeds of intact bitches possess low risks like German Shepherd, Daschunds, and Swedish hounds. Breed susceptibility strongly represents the contribution of genotype towards an increase or decrease risk of disease (Jitpean et al., 2012) ${ }^{[27]}$.

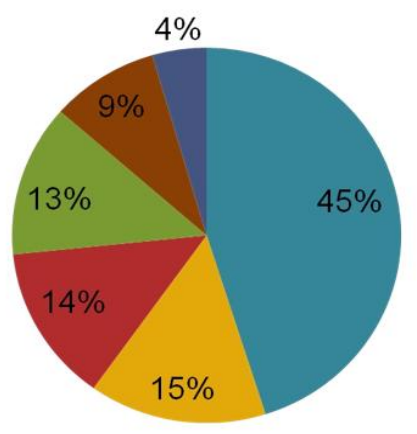

- Spitz

- Labrador

- Alsatian

- Mongrel

- Doberman

Boxer

Fig 1:

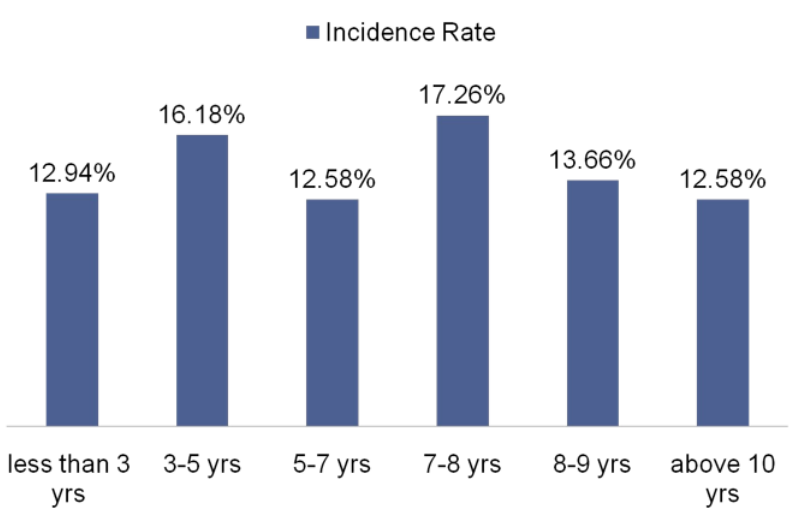

Fig 2:

\section{Etiology}

Several types of research indicated the predominant role of reproductive hormones, i.e., progesterone and estrogen as predisposing factors for pyometra in which the former being the most dominant one. Although the exact etiology of cystic endometrial hyperplasia $(\mathrm{CEH})$ and pyometra is uncertain, this syndrome is probably best categorized as an infectious cause of infertility, even though the role of the endocrine environment is significant. It has been suggested that cystic endometrial hyperplasia, which precedes pyometra as a clinical disease, may cause infertility by allowing the development of mating-induced endometritis (Freeman et al., 2013) ${ }^{[15]}$, conception failure and embryonic resorption. The condition may be recognized by ultrasound examination of the uterus during the luteal phase. Continuing glandular hyperplasia occurs under the influence of progesterone and regresses at the end of the luteal phase. However, during the animal's life, there is progressive hyperplasia, which ultimately results in the development of pathological lesions termed cystic endometrial hyperplasia. The mean age of clinical pyometra is approximately 8 years, but it is not clear whether there is any association with parity or characteristics of the oestrous cycle. Pyometra is, however, very clearly a disease of the luteal phase, with most bitches showing clinical signs between 5 and 80 days after the end of oestrus; progesterone is the main hormone concerned with inducing uterine glandular hyperplasia. Organisms isolated from the uterine fluid in cases of pyometra are those found as part of the normal vaginal and vulvar microflora of healthy bitches. Escherichia coli is the pathogen most commonly isolated from bitches with pyometra (Chen et al., 2003; Hagman and Kuhn, 2002; Hagman et al., 2006) ${ }^{[7,20,21]}$.

\section{Pathogenesis}

Mainly hormonal imbalance or abnormal response to normal concentrations of oestrogens, and progesterone influence the epithelial cells of the uterus and facilitates bacterial adherence, colonization, and growth (Hagman and Kuhn, 2002) ${ }^{[20]}$ that favours the occurrence of disease. During the follicular phase of estrus cycle estrogens increase the uterine cell growth and endometrial vascularization. They increase the uterine sensibility and reaction to progesterone. Progesterone results in endometrial cell proliferation and uterine glandular secretion decreased myometrial contraction and induce closure of the cervix (Borresen, 1975; Smith, 2006) ${ }^{[6,45]}$. Factors associated with bacteria as well as their receptor expression may lead to enhance bacterial attachment to the endometrium (Gabriel et al., 2016) ${ }^{[17]}$.

The uterine response to the presence of microflora is largely based on innate immunity. Wijewardana et al., (2015) [48] described a negative correlation between progesterone on the maturation of antigen-presenting dendritic cells which may lead to the reduction of cell-mediated immunity (CMI). Conserved pathogen-associated molecular patterns (PAMPs) synthesized by the microflora, such as lipopolysaccharide (LPS) for gram-negative bacteria, are recognized by germlineencoded pattern recognition receptors, toll-like receptors (TLRs), which induced the non-specific immune response with the recruitment of inflammatory cells, including neutrophil granulocytes (Horne et al., 2008) ${ }^{[25]}$. The increased level of progesterone hormone concentrations during oestrus in the bitch may result in a less efficient nonspecific immunity, decreasing the expression of toll-like receptors (TLRs) during oestrus and early dioestrus, and allowing the embryo implantation and development (Silva et al., 2012) ${ }^{[43]}$. The concomitant presence of pathogenic microflora such as Escherichia coli during these phases may induce the development of an infection. The bacteria adhere to the endometrium and stimulate the immune response. The expression of TLR2 and TLR4 receptors is increased (Silva et al., 2010) ${ }^{[43]}$, which initiate the secretion of cytokines, cyclooxygenase-2 (COX-2) and prostaglandin E2 and F2a (Silva et al., 2012) ${ }^{[43]}$, causing the local inflammatory response of endometrium.

\section{Clinical Finding}

If the patient is presented early, the general history is that the animal has been lethargic with a reduced appetite; increased thirst and vomiting are variable findings. Some animals may be presented later when there is a vulvar discharge, which in some cases is associated with improvement in general health. In some cases bitch remains unwell due to there is no discharge of pus from the vulva. In the other cases bitch's abdomen may become distended, and she may be thought to be pregnant, although the systemic illness is common. These cases generally end fatally, often within 14 to 21 days from 
the onset of clinical signs; the cervix remains closed throughout. Death may be due to signs of pyometra include endotoxemia, septic shock, peritonitis due to rupture of the uterus, and multiorgan failure. Jitpean et al. (2014) [28] described peritonitis as the most common finding in pyometra which ranges $10 \%$ of total cases. Occasionally, the cervix relaxes, and there is an outpouring of pus just before death.

In a further category, there may be an intermittent opening of the cervix, with relatively good health in comparison to closed cervix after the discharge of pus and malaise during the intervening periods. Some cases of open cervix pyometra may persist for months, with a more or less continuous vulvar discharge. Body temperature may be normal or slightly elevated in cases of open cervix pyometra, whereas there is commonly observe an elevated body temperature in cases of closed cervix pyometra. In toxaemic patients the body temperature may be observed than subnormal. The character of the vulvar discharge may vary considerably. Most often, it is of a thin consistency and light chocolate brown and has a characteristic odor. In other cases, it is yellow, often bloodtinged, and varying from a watery to a creamy consistency. The vulva is generally show enlarged, and there may be discoloration or scalding of the perivulvar tissues and perineum. Increased thirst is commonly observed in advanced cases, which is due to reduced permeability for water in the distal convoluted tubule of the kidney. Renal dysfunction is probably caused by the formation of immune complexes. A small proportion of cases of pyometra develop neurological signs, particularly ear twitching.

Table 1:

\begin{tabular}{|c|c|c|}
\hline Clinical signs & Open-cervix & Close-cervix \\
\hline Vaginal discharge & Watery- creamy; light brown, green or yellow & rare \\
\hline Temperature & normal/slightly elevated & elevated/sub-normal (toxemic bitch) \\
\hline Lethargy/ depression & + & + \\
\hline Vomiting & + & + \\
\hline
\end{tabular}
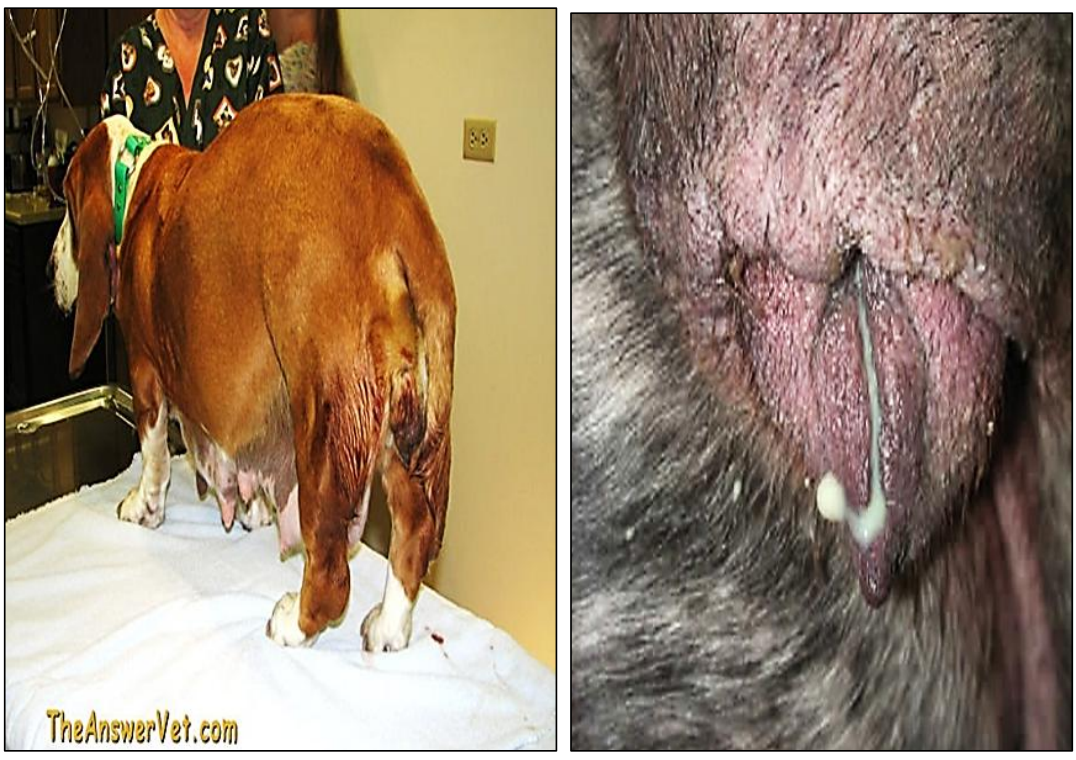

Fig 3: Diestrus bitch with purulent vaginal discharge

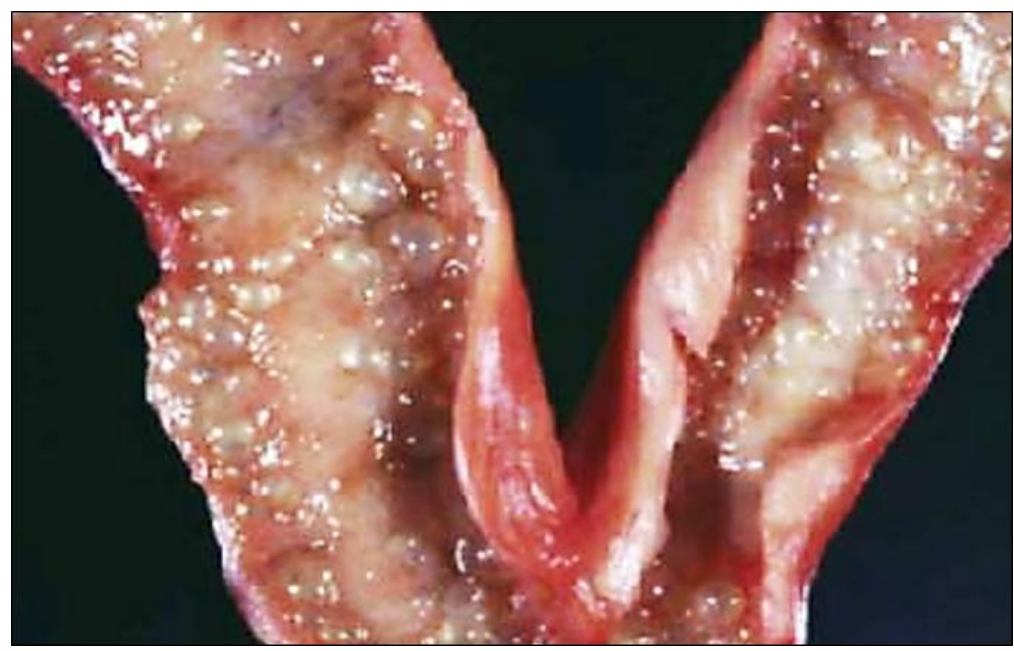

Fig 4: Cystic Endometrial hyperplasia 


\section{Cystic Endometrial hyperplasia Diagnostic Features}

Before abdominal palpation, animals should be allowed to urinate and defecate. But in the case of large or obese patients, abdominal palpation may be difficult. In cases of open cervix pyometra the uterine horns may be detected as thickened, often irregular, and slightly turgid structures from 1 to $3 \mathrm{~cm}$ in diameter. Their position within the abdomen is not generally altered from normal. Occasionally, some areas of the uterine horns are turgid and solid on palpation whereas others, which are distended by pus, may be indistinguishable from the surrounding bowel. Care must be taken not to confuse the colon with thickened uterine horns. In cases of closed cervix pyometra, the degree of uterine distension may be greater, and there may be visible abdominal enlargement. Also palpate the distended uterus per rectum by using a finger, especially if slight backward pressure is applied to the abdominal wall and feel the enlargement of the uterus.

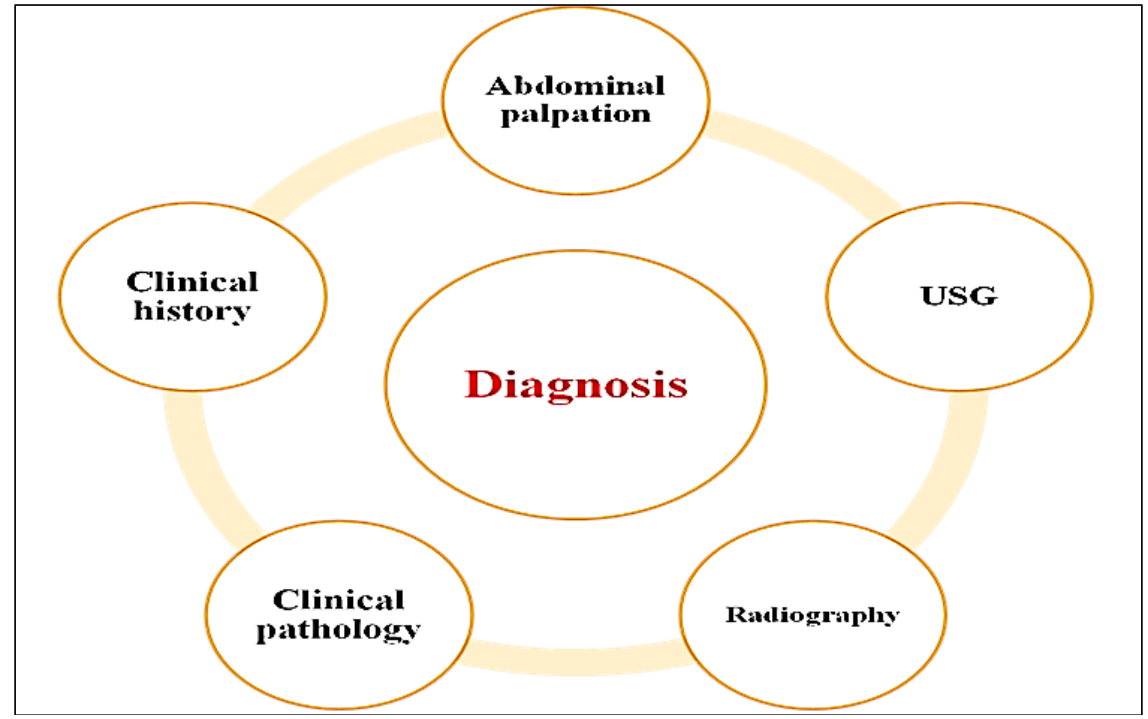

Fig 5:

Ultrasonography is an advanced diagnostic technique is particularly used for detecting the uterus that is filled with fluid. The diagnosis is most simple when the diameter of the uterus increases to larger than that of the small intestine. Ultrasonographic imaging is one of the best diagnostic tools in which uterus is observed as an enlarged and hypoechoic tubular organ containing echogenic fluid (Gupta et al., 2013)
[18], however, sometimes pus exhibits slow, whirlpool-like pattern (Bigliardi et al., 2004) ${ }^{[5]}$. The diameter of the uterus may vary, depending on whether the cervix is open or closed. The uterine wall is usually relatively hypoechoic and is increased in thickness. The uterine lumen is usually grossly dilated with anechoic fluid, although small echogenic particles and mass lesions may be identified.
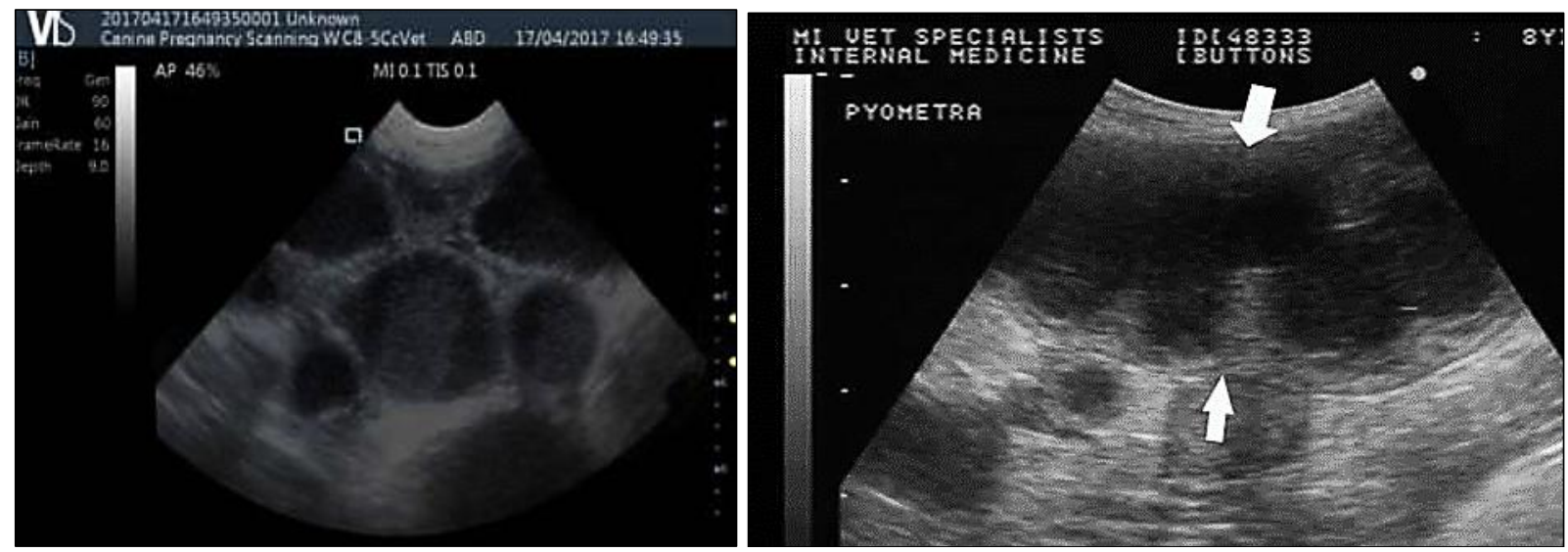

Fig 6: Uterus of bitch with pus

\section{Uterus of Bitch with pus}

Radiographic imaging of the abdominal region shows a softtissue-opacity mass lesion within the caudal abdomen, causing cranial displacement of the small intestine and dorsal displacement of the colon, has been used for some time to indicate enlargement of the uterus. It should be remembered, however, that these findings are not specific for pyometra because early pregnancy has a similar radiographic appearance. 


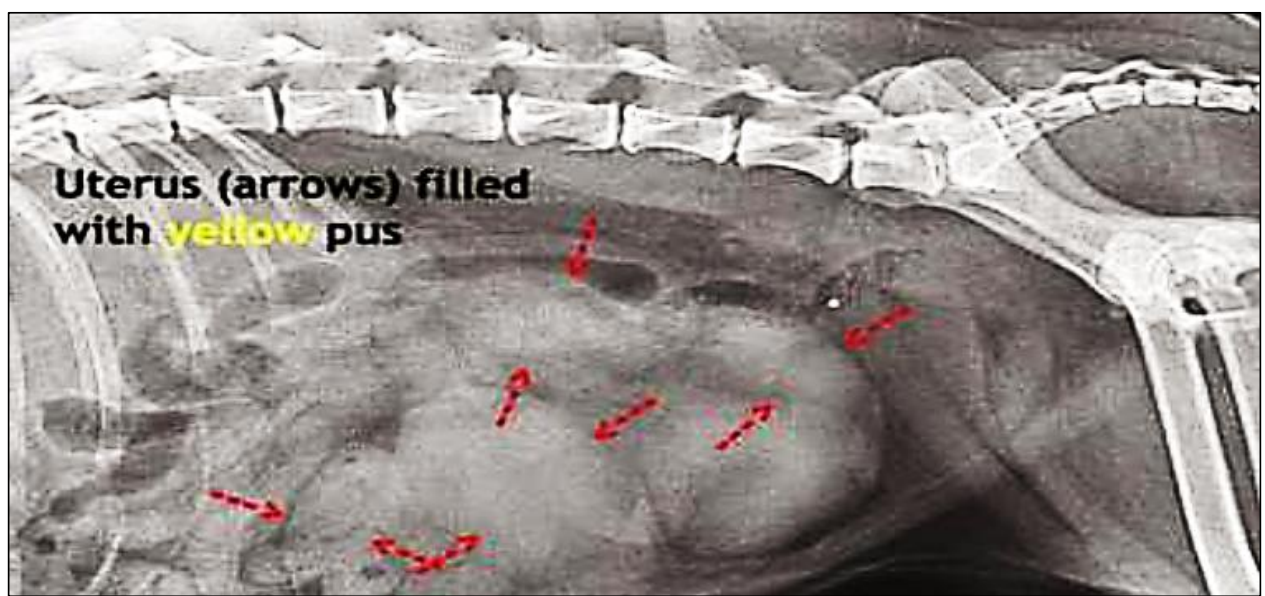

Fig 7: Distended Uterus filled with pus
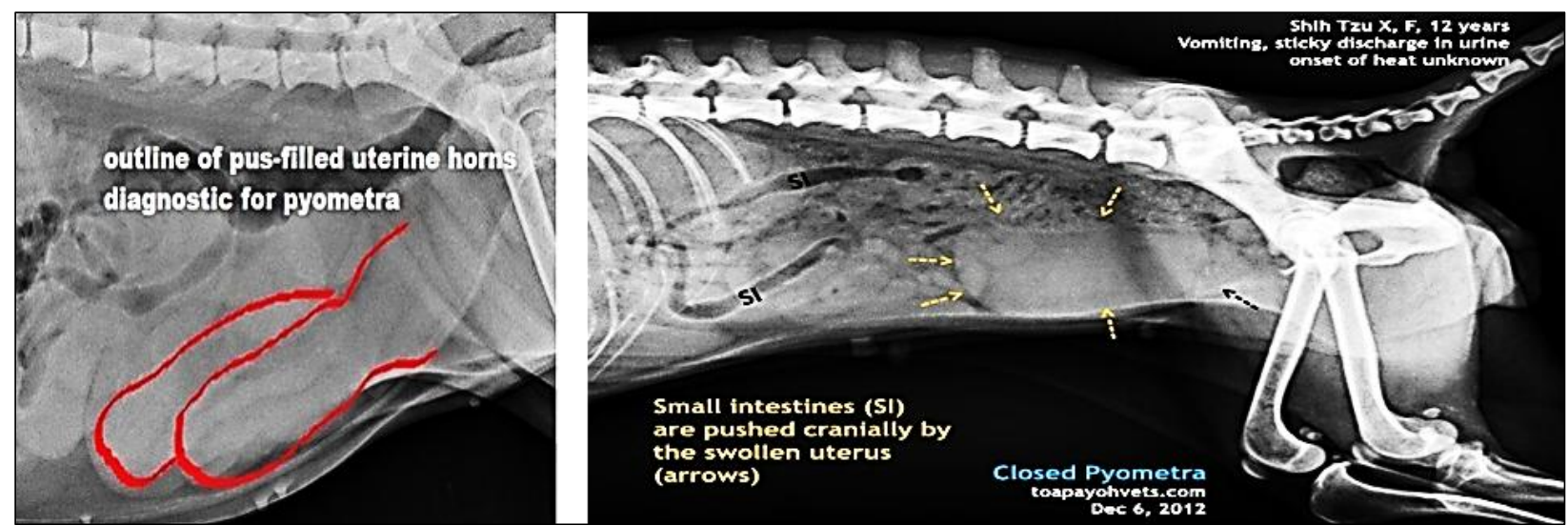

Fig 8:

Hematological analysis shows the total number of leucocytes is frequently elevated in cases of pyometra, although the degree is much less marked in cases of open cervix pyometra compared with closed cervix pyometra. However, an elevated white cell count is not always present. Haematological analysis show reduced level of haemoglobin $(\mathrm{Hb})$, decreased packed cell volume (PCV), azotemia, and leucocytosis with neutrophilia as consistent findings associated with disease (Patil et al., 2013) ${ }^{[36]}$. Gupta and Dhami, (2013) ${ }^{[18]}$ described that reduced level of haemoglobin $(\mathrm{Hb})$, packed cell volume $(\mathrm{PCV})$, total erythrocyte count (TEC) and platelets along with increase level of erythrocyte sedimentation rate (ESR), total leucocytes count (TLC) and polymorphonuclear (PMN) cells indicate toxaemia whereas a raised level of leucocytes, PMN cells, and declining lymphocytes point out recovery from toxemia. Therefore these changes in haematological values can be used as an aid to diagnosis as well as prognosis of canine pyometra (Mohan et al., 2015) ${ }^{[31]}$.

Biochemical evaluation of blood sample shows an increase in serum urea nitrogen, creatinine, ALT, AST, LP, globulin; however albumin level decreases highly significantly thus causing the enhanced ratio of globulin: albumin in pyometra cases (Jitpean et al., 2014) ${ }^{[28]}$. Destruction of tissue due to the effect of endotoxin can be attributed to elevated levels of serum urea nitrogen and creatinine. Hypoalbuminaemia and hyperglobulinaemia can be a shown due to acute-phase reaction and dehydration respectively (Shah et al., 2017) ${ }^{[41]}$.

\section{Treatment}

\section{Surgical Approach}

Ovariohysterectomy is the treatment of choice for closed cervix or open cervix pyometra. Bitches that are presented early in the course of the disease are usually a low surgical risk in comparison to late presented cases. Lower success rates may occur when bitches are toxaemic. Intravenous fluid therapy is essential required in all cases to ensure minimum renal toxic effects. Nowadays the recent technique of surgery Laparoscopic Assisted Ovariohysterectomy (LAOVH) is introduced for the treatment of canine pyometra, which is proved with lower risk sick of a surgery over conventional open method with careful case selection to improve success rate (Adamovich Rippe et al., 2013; Becher-Deichsel et al., 2016) ${ }^{[1,17]}$. 


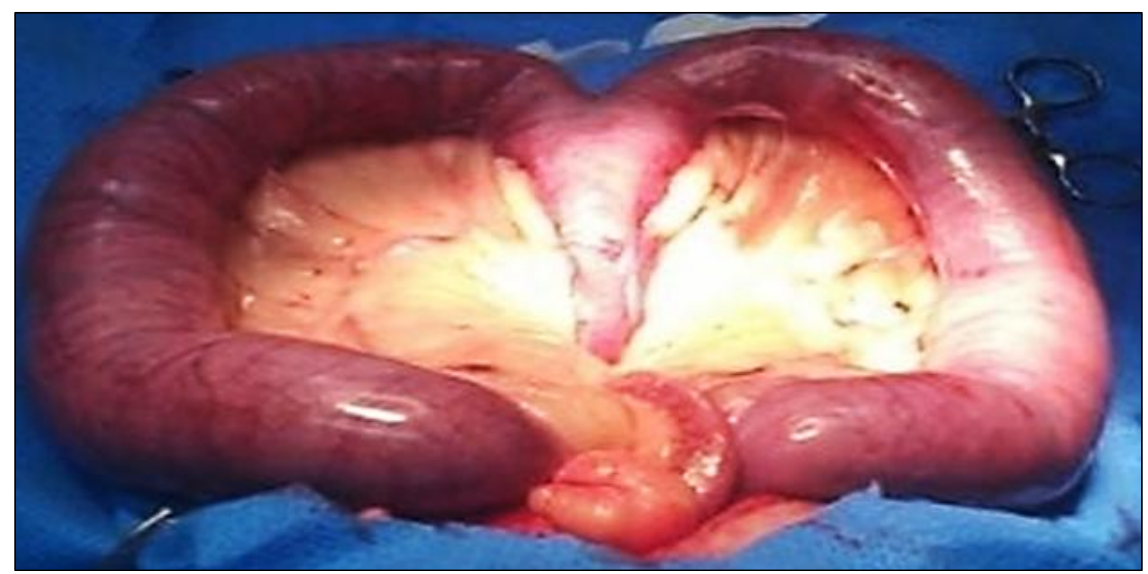

Fig 9:

\section{Medical Approach}

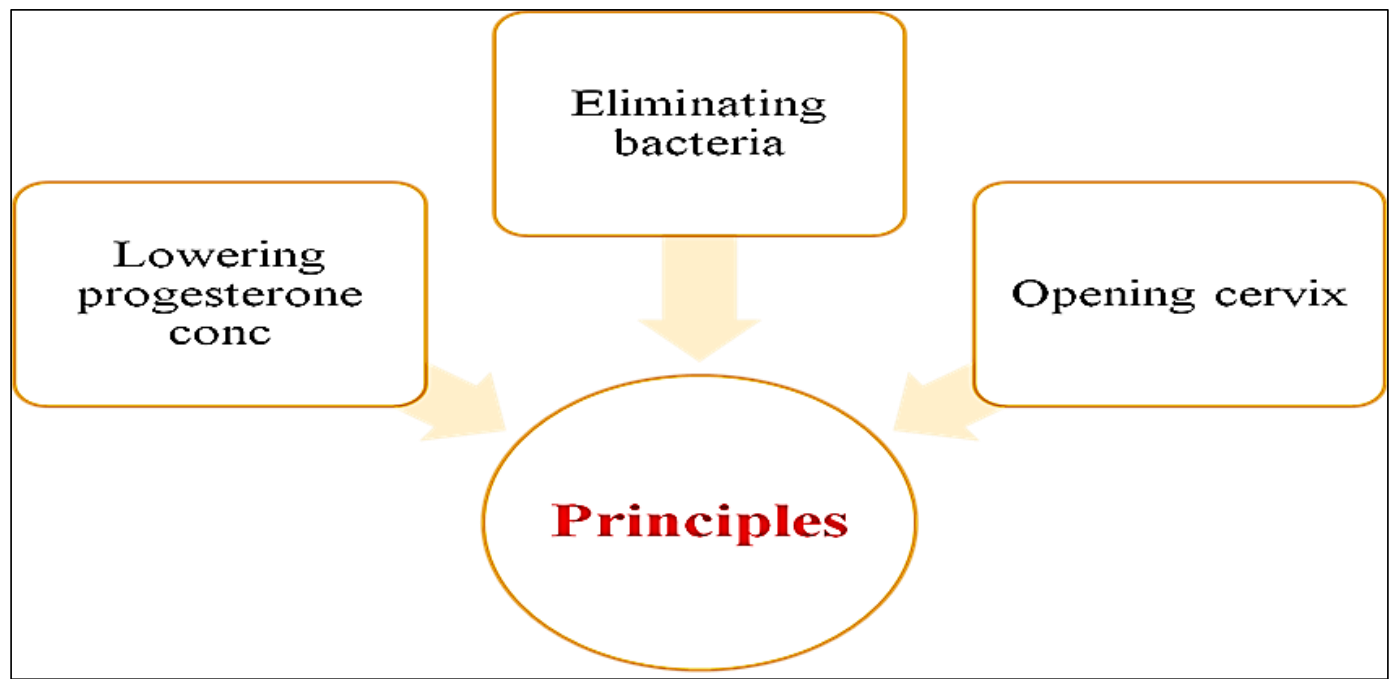

Fig 10:

If the condition is not life-threatening and the animal is enrolled in breeding programmed or particularly valuable or when the clinical situation precludes surgery, medical treatment may be considered. Medical approaches mainly include systemic and intrauterine medication of medicine. Administration of prostaglandin (PGF2 $\alpha$ ) subcutaneous at the @ $150-200 \mu \mathrm{g} / \mathrm{kg} /$ day for more than 10 days showed $100 \%$ results (Myhre, 2016) ${ }^{[33]}$ because PGF2 $\alpha$ causes luteolysis which leads to progesterone block (Renton et al., 1993). Another protocol of treatment of pyometra with a combination of cabergoline @ $5 \mu \mathrm{g} / \mathrm{kg}$ PO once daily and cloprostenol@5 @g / kg every third day subcutaneous for 10 days and potentiated sulphonamide twice a day was recorded enthusiastic results (England et al., 2007) ${ }^{[13]}$. However, in recent times use of progesterone blockers such as mifepristone (Hoffman and Schuler, 2000) ${ }^{[24]}$ or aglepristone (Arnold et al., 2006) [2] are used. Progesterone blocker aglepristone with a combination of prostaglandin has proved better protocol of choice for Cystic endometrial hyperplasiapyometra complex $(\mathrm{CEH} / \mathrm{P})$. The recent combination protocol consisted of aglepristone (@10 mg/kg SC) administration on days 1 (day of diagnosis), 2, 8, and then repeated every 7 days, repeated administration of aglepristone was ceased when the treatment end-point was achieved (normal haematological and biochemical parameter) and Cloprostenol (@ $1 \mu \mathrm{g} / \mathrm{kg}$ SC) was administered daily on days 3-5 is effective and safe, preserving subsequent fertility (Melandri et al., 2019) ${ }^{[30]}$. Appropriate symptomatic therapies (e.g., fluid therapy, antibiotics, nonsteroidal anti-inflammatory drugs, and anti-emetic drugs) were given to patients according to their conditions. Treatment of pyometra typically includes the immediate initiation of antibiotic amoxicillin/clavulanic acid, enrofloxacin, and marbofloxacin therapy. It is likely that, in the future, more complex treatment regimes, involving combinations of these three drugs (prolactin inhibitors, prostaglandins, progesterone receptor antagonists), will prove to be even more efficacious. E Trade Name(S) Presentation Availability

\section{Conclusion}

Canine cystic endometrial hyperplasia (CEH)-pyometra syndrome is a very complex nature of the disease with one of the several reasons for this condition can be lack of complete and detailed information regarding etiopathology. The protocol of treatment of pyometra with a combination of cabergoline and cloprostenol was recorded as enthusiastic results. Progesterone receptor blocker (Aglepristone or mifepristone) alone can be effective and safe for the treatment of metritis and to induce cervical opening in closed pyometra. The recent medicinal combination of aglepristone and cloprostenol was most effective in the medical treatment for open and closed pyometra in comparison to other protocols. Nevertheless, careful selection of pyometra cases is important, and medicinal treatment is contraindicated in 
bitches with hepatorenal failure or peritonitis; clinical parameters should be monitored closely throughout the treatment of bitches. It is found well established medical treatment with maximum recovery rate which can be used as an alternative to the stressful, costly, and laborious surgical approach.

\section{Acknowledgment}

Authors are greatly thankful to the Professor \& Head and staff of the Department of Veterinary Gynaecology and Obstetrics, College of Veterinary Science \& Animal husbandry, ANDUAT Kumarganj Ayodhya.

\section{References}

1. Adamovic-Rippe KN, Philipp DM, Jeffrey JR, William TNC et al.. Evaluation of laparoscopic assisted ovariohysterectomy for treatment of canine pyometra. Vet. Surgery. 2013; 42:572-578.

2. Arnold S, Reichler I, Hubler M. Canine pyometra: new approaches to an old disease. In WSAVA, 2006, 691-692.

3. Arora N, Sandford J, Browning GF, Sandy JR, Wright PJ. A model for cystic endometrial hyperplasia/pyometra complex in the bitch. Theriogenolo. 2006; 66:1530-6.

4. Becher-Deichsel A, Aurich JE, Schrammel N, Dupré G. A surgical glove port technique for laparoscopic-assisted ovariohysterectomy for pyometra in the bitch. Theriogenology. 2016; 86:619-625.

5. Bigliardi E, Prmigiani E, Cavirani S, Luppi A, Bonati L, Corradi A. Ultrasonography and cystic hyperplasiapyometra complex in the bitch. Reprod. Dom. Anim. 2004; 39:136-140.

6. Borresen B. Pyometra in the dog: a pathophysiological investigation. North Vet Med. 1975; 27:508-517.

7. Chen YMM, Wright PJ, Lee CS, Browning GF. Uropathogenic virulence factors in isolates of Escherichia coli form clinical cases of canine pyometra and feces of healthy bitches. Vet Microbiol. 2003; 94 57-69.

8. Debosschere H, Ducatelle R, Vermeirsch H, Van Den Broeck W, Coryn M. Cystic endometrial hyperplasiapyometra complex in the bitch: should the two entities be disconnected. Theriogenology. 2001; 55:1509-19.

9. Dow C. The cystic hyperplasia-pyometra complex in the bitch. Vet Rec. 1957; 69:1409-15.

10. Dow $\mathrm{C}$. The cystic hyperplasia-pyometra complex in the bitch. The Veterinary Record. 1958; 70:1102-1110.

11. Egenvall A, Hagman R, Bonnett BN, Hedhammar A, Olsson P, Lagerstedt AS. Breed risk of pyometra in insured dogs in Sweden. J Vet Inter Med. 2001; 15:530538.

12. Egenvall A, Hedhammar A, Bonnett BN, Olsson. Survey of the Swedish Dog Population: Age, Gender, Breed, Location and Enrollment in Animal Insurance. Acta Vet Scand. 2009; 40(3):231-40.

13. England GCW, Freeman SL, Russo M. Treatment of spontaneous pyometra in 22 bitches with a combination of cabergoline and cloprostenol. Veterinary Record. 2007; 160(9):293-296. Doi:10.1136/vr.160.9.293.

14. Ewald B. A survey of cystic hyperplasia-pyometra complex in the bitch. Small Animal Clinician. 1961; $1: 383-386$

15. Freeman SL, Green MJ, England GC. Uterine fluid from bitches with mating-induced endometritis reduces the attachment of spermatozoa to the uterine epithelium. Vet J. $2013 ; 198: 76-80$.
16. Fukuda S. Incidence of pyometra in colony-raised beagle dogs. Experimental Animals/Japanese Association for Laboratory Animal Science. 2001; 50:325-329.

17. Gabriel C, Becher-Deichsel A, Hlavaty J, Mair G, Walter I. The physiological expression of scavenger receptor SR-B1 in canine endometrial and placental epithelial cells and its potential involvement in pathogenesis of pyometra. Theriogenology. 2016; 85:1599-1609.

18. Gupta AK, Dhami AJ, Patil DB, Kumar D, Darr M. Clinical and ultrasonographic evaluation of Bitches affected with pyometra. Indian J Field Vet. 2013; 8(3):14.

19. Gupta AK, Dhami AJ. Haematological alterations in bitches affected with pyometra. Indian J Field Vet. 2013; 9(1):1-5

20. Hagman R, Kuhn I. Escherichia coli strains isolated from the uterus and urinary bladder of bitches suffering from pyometra: comparison by restriction enzyme digestion and pulsed-field gel electrophoresis. Vet Microbiol. 2002; 84:143-153.

21. Hagman R, Kindahl H, Lagerstedt AS. Pyometra in bitches induces elevated plasma endotoxin and prostaglandin F2 $\alpha$ metabolites levels. Acta Vet Scand. 2006; 47:55-68.

22. Hagman R, Lagerstedt AS, Hedhammar A, Egenvall A. A breed-matched case-control study of potential riskfactors for canine pyometra. Theriogenology. 2011; 75:1251-1257.

23. Hardy RM, Osborne CA. Canine pyometra: pathophysiology, diagnosis and treatment of uterine and extra-uterine lesions. J Am Anim Hosp Assoc. 1974; $10(3): 245-268$.

24. Hoffmann B, Schuler G. Receptor blockers-general aspects with respect to their use in domestic animal reproduction. Anim. Reprod. Sci. 2000; 60(61):295-312.

25. Horne AW, Stock SJ, King AE. Innate immunity and disorders of the female reproductive tract. Reproduction. 2008; 135:739-749.

26. Igna V. Associations between hormonal therapy, pyometra, and canine mammary tumours. Lucrari Stiintifice - Universitatea de Stiinte Agricole a Banatului Timisoara, Medicina Veterinary. 2011; 44:33-40.

27. Jitpean S, Hagman R, Ström Holst B, Höglund OV, Pettersson A, Egenvall A. Breed variations in the incidence of pyometra and mammary tumours in Swedish dogs. Reprod. Domes. Anim. 2012; 47(6):347-350.

28. Jitpean S, Ström-Holst B, Emanuelson U, Höglund OV, Pettersson A, Alneryd-Bull C et al. Outcome of pyometra in female dogs and predictors of peritonitis and prolonged postoperative hospitalization in surgically treated cases. BMC Vet. Res. 2014; 10:6.

29. Kennedy PC, Miller RB. The female genital system. In: Palmer N, editor. Pathology of domestic animals. Academic Press, 1993, 349-86.

30. Melandri M, Veronesi MC, Pisu MC, Majolino G, Alonge S. Fertility outcome after medically treated pyometra in dogs. Journal of Veterinary Science. 2019; 20(4).

31. Mohan P, Subramanian A, Nambi AP. Haematological changes in open cervix pyometra following PGF2á therapy in canines. Indian J Vet. Sci. Biotech, 2015, 11(1).

32. Moxon R, Whiteside H, England GCW. Prevalence of ultrasound-determined cystic endometrial hyperplasia 
and the relationship with age in dogs. Theriogenology. 2016; 86(4):976-980.

33. Myhre AS. Canine Pyometra: the Efficiency of Medical Treatment of Pyometra - Integrated Studies of Veterinary Medicine. Master theses. Faculty of Veterinary Medicine Lithuanian University of Health Sciences Veterinary Academy, 2016.

34. Niskanen M, Thrusfield MV. Associations between age, parity, hormonal therapy and breed, and pyometra in Finnish dogs. Vet Rec. 1998; 143(18):493-498.

35. Noakes DE, Parkinson TJ, England GCW. Veterinary Reproduction and Obstetrics, Saunders, 2009.

36. Patil AR, Swamy M, Chandra A, Jawre S. Clinicohaematological and serum biochemical alterations in pyometra affected bitches. Afri. J Biotechnol. 2013; 12(13):1564-1570.

37. Pretzer SD. Clinical presentation of canine pyometra and mucometra: A review. Theriogenology. 2008; 70:359363.

38. Renton JP, Boyd JS, Harvey MJA. Observations on the treatment and diagnosis of open pyometra in the bitch (Canis familiaris). J Reprod. Fertil.. Suppl. 19931; 47:465-469.

39. Sandholm M, Vasenius H, Kivisto AK. Pathogenesis of canine pyometra. J Am. Vet. Med. Assoc. 1975; 167(11):1006-1010.

40. Sevelius E, Tidholm A, Thorentolling K. Pyometra in the Dog. Journal of the American Animal Hospital Association. 1990; 26: 33-38.

41. Shah SA, Sood NK, Wani BM, Rather MA, Beigh AB, Amin U. Haematobiochemical studies in canine pyometra. J Pharmacogn. Phytochem. 2017; 6(4):14-17.

42. Shiju Simon, Ganesh MR, Arunprasad A, Suresh Kumar R. Incidence of pyometra in bitches-A Survey of 278 cases. Tamilnadu J Veterinary \& Animal Sciences. 2011; 7(5):252-253.

43. Silva E, Henriques S, Brito S, Ferreira-Dias G, Lopes Da Costa L, Mateus L. OEstrous cycle-related changes in production of Toll-like receptors and prostaglandins in the canine endometrium. J Reprod Immunol. 2012; 96:45-57.

44. Silva E, Leitao S, Henriques S, Kowalewski MP, Hoffmann B, Ferreira-Dias G et al. Gene transcription of TLR2, TLR4, LPS ligands and prostaglandin synthesis enzymes are up-regulated in canine uteri wih cystic endometrial hyperplasia-pyometra complex. J Reprod Immunol. 2010; 84:66-74.

45. Smith FO. Canine pyometra. Theriogenology. 2006; 66:610-612.

46. Wheaton LG, Johnson AL, Parker AJ, Kneller SK. Results and complications of surgical-treatment of pyometra- a review of 80 cases. J Am Anim Hosp Assoc. 1989; 25(5):563-568.

47. Whitehead ML. Risk of pyometra in bitches treated for mismating with low doses of oestradiol benzoate. The Veterinary record. 2008; 162:746-749.

48. Wijewardana V, Sugiura K, Wijesekera DP, Hatoya S, Nishimura T, Kanegi R et al. Effect of ovarian hormones on maturation of dendritic cells from peripheral blood monocytes in dogs. J Vet. Med. Sci. 2015; 77:771-775. 